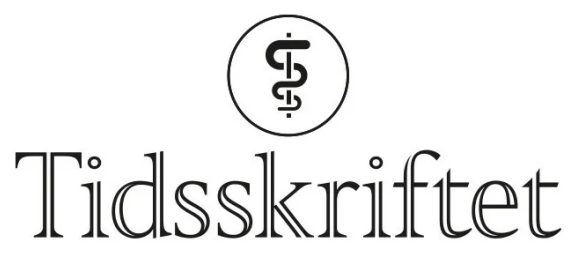

DEN NORSKE LEGEFORENING

\title{
H.S. Jensen og I.A. Lindseth svarer
}

\author{
KOMMENTAR \\ HANNE STORHAUG JENSEN \\ hanneskjokken@gmail.com \\ Hanne Storhaug Jensen er daglig leder for Spirene org., Nesodden.
}

INGE ANDREAS LINDSETH

Forfatterne har ikke oppgitt noen interessekonflikter.

Gir redusert inntak av mettet fett på bekostning av flerumettet redusert forekomst av koronare hendelser og død? Dette er det overordnede spørsmålet i vår debattartikkel i Tidsskriftet (1). Kostrådene gir inntrykk av at evidensen er sterk, men i vårt innlegg pekte vi på at konklusjonene ikke stemmer overens med datagrunnlaget. Arnesen m.fl. adresserer ikke dette hovedpoenget.

For å gradere evidensen som overbevisende skulle dataene vise konsistente sammenhenger mellom sykdom og eksponering, med lite eller ingen dokumentasjon for det motsatte (므). Men evidensen fra prospektive kohortstudier, som Helsedirektoratet refererer til, inneholder betydelige funn som taler mot rådene. Eksempler er økt risiko for koronar hjertesykdom ved å erstatte mettet fett med karbohydrater (3) og sterk signifikant sammenheng mellom høyere inntak av flerumettet fett og koronar dødelighet (4.). Metaanalyser av kliniske studier brukes for å støtte opp om rådene (4,.5), men analysene har inkludert studier med store forskjeller mellom gruppene ut over inntaket av mettet og flerumettet fett. Eksempelvis har det vært forskjeller i transfett og i det kardiotoksiske legemiddelet tioridazin (므). Metaanalyser som inkluderer slike multifaktorielle studier er åpenbart ikke egnet til å svare på spørsmålet om utskifting av mettet fett med flerumettet kan redusere forekomsten av koronare hendelser og død. Videre, når de nyeste tallene fra Sydney Diet Heart Study og Minnesota Coronary Experiment tas hensyn til, faller støtten fra kliniske studier helt bort, uansett om man inkluderer de multifaktorielle studiene. At støtten for rådene om fett er svak er også påpekt i Helsedirektoratets hovedkilde (4.): «The available evidence from cohort and randomized controlled trials is unsatisfactory and unreliable to make judgment about and substantiate the effects of dietary fat on risk of CHD.»

Vi mener det burde være strengere kvalitetskontroll av de endelige kostrådene. Med dagens system - der ekspertene både lager og godkjenner rapportene, og der det i liten grad beskrives hvordan studiene velges og vektes - er det umulig for utenforstående å forstå hva som eventuelt skal til for at rådene om fett skal tas bort. 


\section{LITTERATUR}

1. Jensen HS, Lindseth IA. Manglende kvalitetssikring av kostholdsrådene. Tidsskr Nor Legeforen 2021; 141. doi: 10.4045/tidsskr.21.0214. [PubMed][CrossRef]

2. Diet, nutrition and the prevention of chronic diseases. Report of a Joint WHO/FAO Expert Consultation. WHO technical report series, no. 916. Genève: WHO, 2003. http://apps.who.int/iris/bitstream/handle/10665/42665/WHO_TRS_916.pdf;jsessionid=F13B29316E2oE EFBDCoD533D2269BAgo? sequence=1 Lest 1.7.2021.

3. Jakobsen MU, O'Reilly EJ, Heitmann BL et al. Major types of dietary fat and risk of coronary heart disease: a pooled analysis of 11 cohort studies. Am J Clin Nutr 2009; 89: 1425-32. [PubMed][CrossRef]

4. Skeaff CM, Miller J. Dietary fat and coronary heart disease: summary of evidence from prospective cohort and randomised controlled trials. Ann Nutr Metab 2009; 55: 173-201. [PubMed][CrossRef]

5. Mozaffarian D, Micha R, Wallace S. Effects on coronary heart disease of increasing polyunsaturated fat in place of saturated fat: a systematic review and meta-analysis of randomized controlled trials. PLoS Med 2010; 7: e1000252. [PubMed][CrossRef]

6. Ramsden CE, Hibbeln JR, Majchrzak SF et al. n-6 fatty acid-specific and mixed polyunsaturate dietary interventions have different effects on CHD risk: a meta-analysis of randomised controlled trials. Br J Nutr 2010; 104: 1586-6oo. [PubMed][CrossRef]

Publisert: 16. august 2021. Tidsskr Nor Legeforen. DOI: 10.4045/tidsskr.21.0526

(C) Tidsskrift for Den norske legeforening 2023. Lastet ned fra tidsskriftet.no 26. april 2023. 